\title{
Karakterisasi Senyawa Antibakteri Ekstrak Air Daun Kecombrang (Etlingera elatior)
}

\author{
Dede Sukandar ${ }^{1}$, Nani Radiastuti ${ }^{2}$, Ira Jayanegara ${ }^{3}$, Rina Ningtiyas ${ }^{2}$ \\ ${ }^{1)}$ Program Studi Kimia dan ${ }^{2)}$ Program Studi Biologi \\ Fakultas Sains dan Teknologi UIN Syarif Hidayatullah Jakarta, \\ Jalan Ir. H. Juanda No 95 Ciputat 15412 Indonesia \\ ${ }^{3)}$ Badan Pengkajian dan Penerapan Teknologi, BPPT Jakarta \\ e-mail:d_sukandar@hotmail.com
}

\begin{abstract}
Abstrak
Telah dilakukan penelitian mengenai pengujian aktivitas antibakteri dari ektrak air daun kecombrang (Etlingera elatior) yang bertujuan memberikan bukti ilmiah keunggulan tanaman kecombrang sebagai bahan pangan fungsional. Pengujian antibakteri dilakukan dengan metode difusi cakram dan identifikasi ko mponen kimia dengan alat GCMS. Ekstrak air daun keco mbrang bersifat antibakteri E. Coli (zona hambat $10 \mathrm{~mm} / 100 \%$ ), S. Aureus (zona hambat 8,663 mm/20\%. Ekstrak air daun kecombrang memiliki komponen utama 2,3-butanadiol ( $\mathrm{tR}=5,28$, area $=29,38$, kemiripan $90 \%$ ) dan fenol ( $\mathrm{tR}=6,83$, area $=2,26$, ke miripan $90 \%)$.
\end{abstract}

Kata Kunci: kecombrang (Etlingera elatior), pangan fungsional dan antibakteri

\begin{abstract}
A research which antibacterial activity test from water extract of leaf kecombrang ( Etlingera Elatior) to give erudite evidence excellence of crop kecombrang upon which the functional food. Examination of antibacterial with disk diffusion method and chemical component identified with GCMS instrument. Water extract of kecombrang leaf have the character of antibacterial E. Coli ( zona of inhibition $10 \mathrm{~mm}$, at concentration 100\%), S. Aureus ( zona of inhibition 8,663 mm, at concentration 20\%). Water extract kecombrang leaf have component 2,3-butanadiol ( $\mathrm{tR}=5,28$, area $=29,38$, similarity at $90 \%$ ) and phenol $(\mathrm{tR}=6,83$, area $=2,26$, similarity at $90 \%)$.
\end{abstract}

Keywords: kecombrang ( Etlingera Elatior), food fungsionl and antibacterial

\section{PENDAHULUAN}

$\begin{array}{cr}\text { Menurut Peraturan Menteri Kesehatan } \\ \text { Nomor } & \text { 722/Menkes/Per/IX/88, bahan }\end{array}$ pengawet makanan merupakan bahan tambahan makanan yang mencegah atau menghambat fermentasi, pengasaman atau penguraian lain terhadap makanan yang disebabkan oleh mikroorganisme (Fardiaz, 2002).

Efektivitas dari bahan pengawet ditentukan oleh konsentrasi, macam bahan pengawet, dan lingkungan bagi bahan pengawet itu ditambahkan. Umumnya semakin tinggi konsentrasi bahan pengawet yang diberikan semakin besar pula efektivitasnya, jika bahan pengawet tidak membahayakan bagi kesehatan (Supardi dan Sukamto, 1999). Sedangkan, menurut Food and Drugs Administration (FDA), keamanan suatu pengawet makanan harus mempertimbangkan jumlah yang mungkin dikonsumsi dalam produk makanan atau jumlah zat yang akan terbentuk dalam makanan dari penggunaan pengawet, efek akumulasi dari pengawet dalam makanan dan potensi toksisitas yang dapat terjadi dari pengawet jika dicerna oleh manusia atau hewan termasuk potensi menyebabkan kanker (Andrew, 2006).

Dalam rangka menghambat proses kerusakan pangan digunakan bahan pengawet sintetis seperti formalin, asam benzoat, BHA (Butilated Hydroxyanisol), BHT (Butylated Hidroxytoluene) dan TBHQ (Tertier Butylated Hydroxyanisole) terutama untuk bahan makanan semi basah seperti tahu, mie, bakso, ikan, daging serta minyak/lemak (Tranggono, 1990). 
Pada saat ini penggunaan bahan pengawet sintetis tidak direkomendasikan oleh Badan Pengawas Obat dan Makanan (BPOM) karena diduga dapat menimbulkan penyakit kanker (carcinogen agent). Karena itu perlu dicari alternatif lain yaitu bahan pengawet alami yang bersumber dari bahan alam. Bahan pengawet alami ini hampir terdapat pada semua tumbuh-tumbuhan dan buah-buahan tersebar di seluruh tanah air (Barus, 2009).

Salah satunya adalah kecombrang (Etlingera elatior), yang merupakan tanaman rempah asli Indonesia termasuk keluarga tanaman Zingiberaceae (Gambar 1), yang

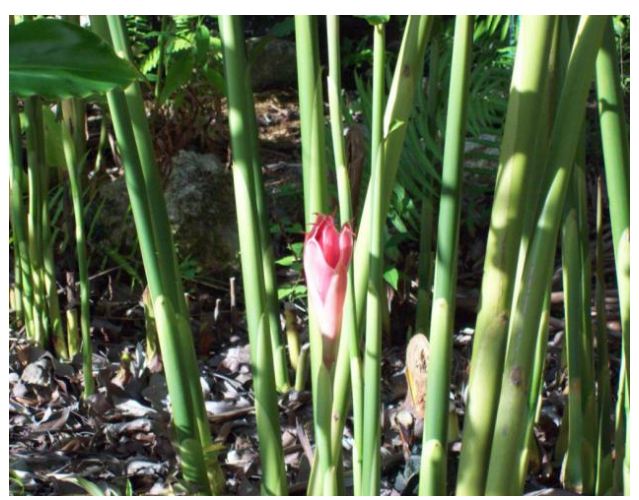

(a) secara tradisional telah lama digunakan masyarakat sebagai salah satu jenis sayuran dan juga digunakan sebagai pengobat luka dan penghilang bau badan (Hidayat dan Hutapea, 1991).

Mengingat adanya potensi dari daun kecombrang (E. elatior) sebagai pengawet alami, maka perlu dilakukan penelitian terkait kemampuannya sebagai antibakteri terutama pada ekstrak airnya. Penekanan ekstrak air menjadi penting agar dapat diterapkan dalam pembuatan makanan sehari-hari maupun industri makanan.

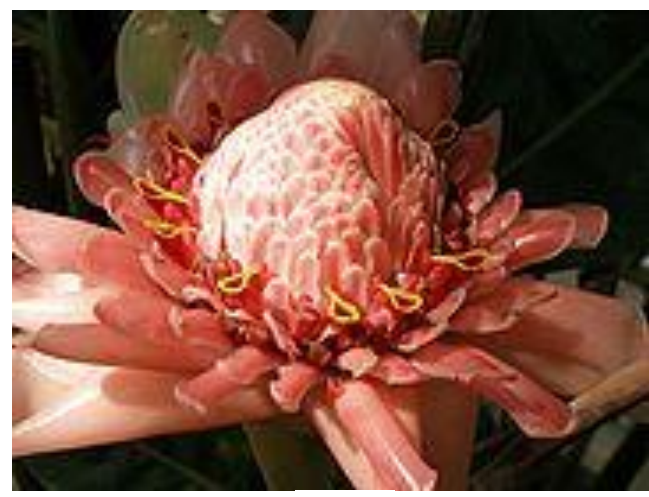

(b)

Gambar 1. Tanaman (a) dan bunga kecombrang (b)

\section{METODE PENELITIAN}

Umum. Ekstraksi dilakukan dengan maserasi selama $3 \times 24$ jam. Pengujian antibakteri dilakukan dengan metode difusi cakram dan analisa komponen kimia dalam ekstrak air daun kecombrang menggunakan alat Gas Chromatography-Mass Spectroscopy, GCMS.

Bahan. Bahan yang digunakan berupa biakan Staphylococcus aureus, dan Escherichia coli yang diperoleh dari culture collection Lab Mikrobiologi Pusat Laboratorium Terpadu UIN Jakarta; medium pemeliharaan bakteri Nutrient Agar (NA, Pronadisa), Nutrient Broth (NB, Pronadisa), Plate Count Agar (PCA, Pronadisa); bahan kimia terdiri dari metanol dan antibiotuk kloramfenikol serta bahan alam berupa daun kecombrang.

Ekstraksi. Sebanyak 500 gram sampel daun kecombtang kering dimaserasi dalam 1 liter pelarut akuades selama 3 x 24 jam. Hasil ekstraksi disaring, dipekatkan menggunakan rotary evaporator dan selanjutnya dipergunakan pada pengujian antibakteri dan analisa komponen kimia.

Uji Antibakteri. Sebanyak 2,4 g NA ditimbang dan dilarutkan dalam $100 \mathrm{ml}$ akuades, selanjutnya dipanaskan sehingga NA larut, dan dituang ke dalam beberapa tabung reaksi masing-masing sebanyak $5 \mathrm{ml}$ dan sisanya dituang ke dalam tabung Erlenmeyer $100 \mathrm{ml}$. Media disterilisasi dalam autoklaf pada suhu $121{ }^{\circ} \mathrm{C}$ selama 15 menit. Setelah media steril, dimiringkan dan dibekukan. Media dalam tabung Erlenmeyer yang sudah disterilisasi dituang ke da lam cawan petri steril untuk membuat agar plat.

Bakteri yang akan digunakan diremajakan sebanyak 3 biakan murni, 1 sebagaai biakan stok dan 2 sebagai biakan kerja. Biakan tersebut ditumbuhkan pada agar miring NA selama 24 jam pada suhu $37^{\circ} \mathrm{C}$.

Biakan yang telah tumbuh pada agar miring NA ditambahkan dengan $5 \mathrm{ml}$ akuades steril. Pengerikan dilakukan menggunakan ose, 
sehingga diperoleh suspensi spora, kemudian dikocok menggunakan vortex supaya homogen. Suspensi spora dimasukkan ke dalam erlenmeyer $100 \mathrm{ml}$ steril.

Suspensi sel bakteri diencerkan sampai pengenceran $10^{-7}$, kemudian disebar pada permukaan NA steril dalam cawan petri. Inkubasi dilakukan pada suhu $37^{\circ} \mathrm{C}$ selama 7 hari. Cara menentukan jumlah mikroorganisme per $\mathrm{ml}$ suspensi dilakukan dengan membagi jumlah koloni terhitung dengan volume suspensi yang diinokulasi dan dibagi dengan pengenceran yang digunakan.

Medium agar (NA) sebanyak $10 \mathrm{ml}$ dicairkan dalam penangas air, kemudian didinginkan sampai suhunya kurang lebih $40^{\circ}$ C. $1 \mathrm{ml}$ berbagai ekstrak berbagai konsentrasi dimasukkan ke medium agar NA steril, kemudian distirrer. 0,1 ml suspensi biakan bakteri (pengenceran $10^{6}$ ) diteteskan ke dalam cawan petri steril. Medium agar dituangkan secara aseptik ke dalam setiap cawan petri yang sudah ditetesi suspensi biakan bakteri, diratakan dengan cara menggoyang dan dibiarkan mengeras. Biakan diinkubsi selama 24 jam, 48 jam dan 72 jam pada suhu kamar, kemudian di lakukan perhitungan jumlah koloni.

Salah satu inokulum aktif bakteri uji sebanyak 0,1 ml dimasukkan kedalam cawan petri steril, kemudian ditambah $10 \mathrm{ml}$ media NA steril suhu $40{ }^{\circ} \mathrm{C}$ diratakan dengan cara diputar diatas meja sehingga tercampur inokulum dan media. Setelah itu, didiamkan sampai membeku dan dilubangi dengan diameter $5 \mathrm{~mm}$ dengan menggunakan pipet steril yang sudah dipotong bagian ujungnya. Lubang/sumur dibuat 3 dalam satu cawan sebagai perlakuan 3 kali ulangan. Salah satu konsentrasi minyak atsiri ditetesi ke lubang yang sudah dibuat sampai batas tinggi sumur yang dibuat. Kemudian diinkubasi pada suhu $37^{\circ} \mathrm{C}$ selama 24 jam. Diameter zona hambat yang terbentuk diukur dengan menggunakan jangka sorong. Hal yang sama dilakukan pada bakteri dan konsentrasi la innya. Kontrol yang digunakan akuades steril. Antibiotik spektrum luas kloramfenicol akan dipakai sebagai pembanding.

Analisa GCMS. Karakterisasi ekstrak air bunga dan daun kecombrang dilakukan dengan menggunakan GCMS Agilent Agilent 19091S436. menggunakan kolom polar HP-5MS 0.25 x 60 x $0.25 \mathrm{~mm}$, suhu oven $\left(70^{\circ} \mathrm{C}-325^{\circ} \mathrm{C}\right)$, Interface $\left(290{ }^{0} \mathrm{C}\right)$, kontrol mode (split), tekanan $(16.30 \mathrm{psi})$, total flow $(40.0 \mathrm{ml} / \mathrm{min})$, split ratio (50:1), split flow $(49,3 \mathrm{~m} / \mathrm{min})$, gas (He), gas saver (On), dan detektor (MSD).

Analisis Data. Semua perlakuan diulang tiga kali dari sampel yang berbeda dan akan diuji dengan analisis sidik ragam (ANOVA).

\section{HASIL DAN PEMBAHASAN}

Hasil ekstraksi 90 gram kecombrang (Etlingera elatior) kering dalam $1500 \mathrm{ml}$ akuades dengan cara maserasi diperoleh $59 \mathrm{ml}$ ekstrak kental. Selanjutnya ekstrak tersebut digunakan untuk pengujian aktivitas antibakteri dan analisa GCMS.

Aktivitas antibakteri ekstrak air daun kecombrang diukur berdasarkan zona hambat, hasilnya dapat dilihat pada Gambar 2.

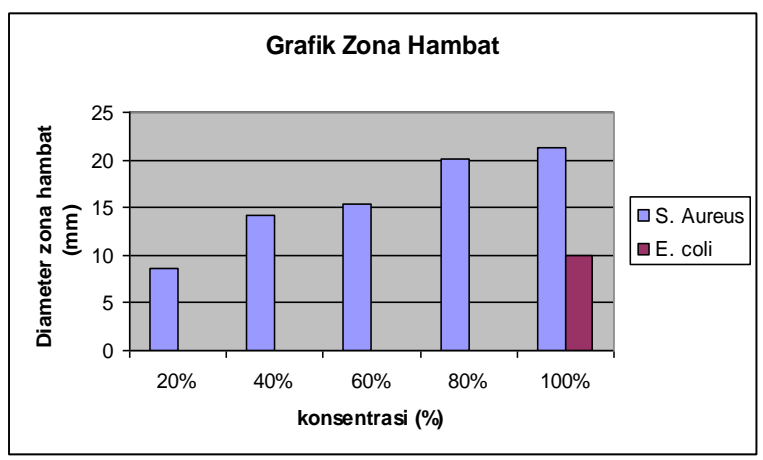

Gambar 2. Zona hambat ekstrak air daun kecombrang

Hasil pengujian antibakteri ekstrak air daun kecombrang terhadap $S$. aureus pada konsentrasi $20 \%, 40 \%, 60 \%, 80 \%$ dan 100 $\%$ menghasilkan zona hambat sebesar 8,663 $\mathrm{mm}, 14,223 \mathrm{~mm}, 15,33 \mathrm{~mm}, 20,08 \mathrm{~mm}$, dan 21,36 mm. Hasil uji aktivitas antibakteri ini menunjukkan semakin tinggi konsentrasi ekstrak, maka semakin tinggi daya hambatnya. Menurut Jenie dan Kuswanto (1994) bahwa keefektifan suatu zat antimikroba dalam menghambat pertumbuhan tergantung pada sifat mikroba uji, konsentrasi dan lamanya waktu kontak. Sifat biostatistik dapat meningkat dengan semakin tingginya konsentrasi yang ditambahkan.

Ekstrak air daun kecombrang menghambat pertumbuhan $E$, coli hanya pada konsentrasi $100 \%$ yaitu dengan zona hambat 
sebesar $10 \mathrm{~mm}$. Hal ini disebabkan aktivitas antimikroba juga dipengaruhi oleh pelarut yang digunakan dalam proses ekstraksi. Air adalah pelarut yang cenderung polar, maka senyawa antibakteri yang terekstrak juga relatif polar. Kepolaran senyawa antibakteri inilah yang mengakibatkan senyawa ini lebih mudah menembus dinding sel bakteri gram positif. Menurut Best (1999), molekul-molekul yang bersifat hidrofilik lebih mudah melewati lipopolisakarida dibandingkan dengan yang hidrofobik. Pada bakteri gram positip tidak ada lapisan lipopolisakarida, sehingga molekul senyawa antimikroba yang bersifat hidrofilik maupun yang hidrofobik dapat melewatinya.

Menurut Kanazama et al. (1995) suatu senyawa yang mempunyai polaritas optimum akan mempunyai aktivitas antimikroba maksimum, karena untuk interaksi suatu senyawa antibakteri dengan bakteri diperlukan keseimbangan hidrofilik-hidrofilik (HLB, hydrophilic lipopphilic balance). Polaritas senyawa merupakan sifat fisik senyawa antimikroba yang penting. Sifat hidrofilik diperlukan untuk menjamin senyawa antimikroba larut dalam fase air yang merupakan tempat hidup mikroba; tetapi senyawa yang bekerja pada membran sel hidrofobik memerlukan pula sifat lipofilik; sehingga senyawa antibakteri memerlukan keseimbangan hidrofilik-hidrofilik untuk mencapai aktivitas yang optimal (Branen dan Davidson, 1993).

Berdasarkan analisa statistik menggunakan anova satu arah pada ekstrak air daun kecombrang terhadap $S$. aureus diperoleh hasil analisa, H0 diterima dan H1 ditolak, sehingga hipotesis yang diterima adalah tidak ada perbedaan yang nyata dan signifikan setiap perlakuan konsentrasi terhadap diameter zona hambat. Hal ini berarti diameter zona hambat dipengaruhi oleh perlakuan konsentrasi bukan oleh sebab lain.

Pada pengujian antibakteri ekstrak air daun kecombrang dengan menggunakan metode difusi cakram menggunakan kontrol positif kloramfenikol $(10 \mu \mathrm{g})$ diperoleh hasil yang dapat dilihat pada gambar dibawah ini.

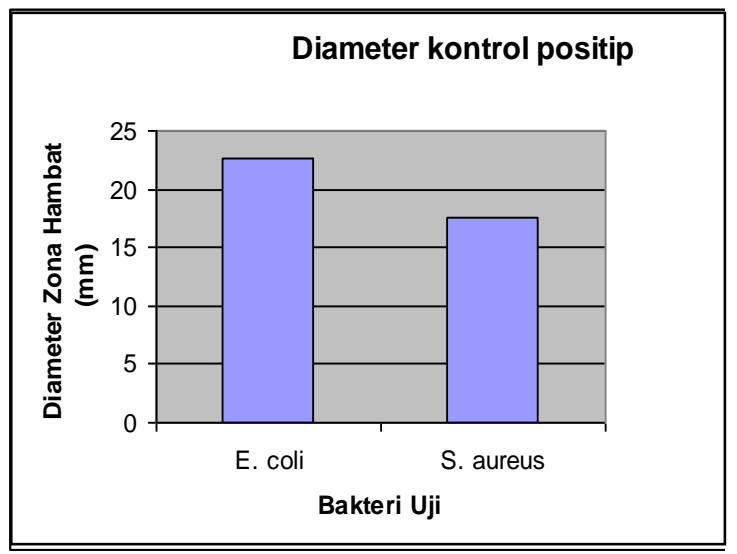

Gambar 3. Diameter zona hambat bakteri uji terhadap klora mfenikol

Berdasarkan data tersebut. diketahui bahwa kloramfenikol merupakan antibiotik yang memiliki spektrum luas atau memiliki kemampuan menghambat pertumbuhan bakteri gram positif maupun negatif pada $10 \mu \mathrm{g}$. Zona hambat kloramfenikol terhadap $S$. aureus dan E. coli sebesat $17,5 \mathrm{~mm}$ dan 22,66 mm. Dari hasil diketahui kalau kedua bakteri itu memiliki sifat sensitif terhadap kloramfenikol. Prescott dan Klein (2009) menuliskan bahwa kondisi bekteri terhadap kloramfenikol dibagi tiga yaitu yang memiliki diameter $12 \mathrm{~mm}$ termasuk resisten, $13-17 \mathrm{~mm}$ termasuk intermediet dan lebih dari $18 \mathrm{~mm}$ merupakan bakteri yang sensitif pada $30 \mu \mathrm{g}$.

Diameter zona hambat ekstrak air daun kecombrang konsentarasi $60 \%$ mendekati zona hambat kloramfenikol $10 \mu \mathrm{g}$, yaitu $15,33 \mathrm{~mm}$. Namun pada E. coli zona hambat ekstrak air daun kecombrang sangat berbeda bila dibandingkan dengan zona hambat kloramfenikol.

Hasil analisa GCMS ekstrak air daun kecombrang terlihat pada gambar berikut. 


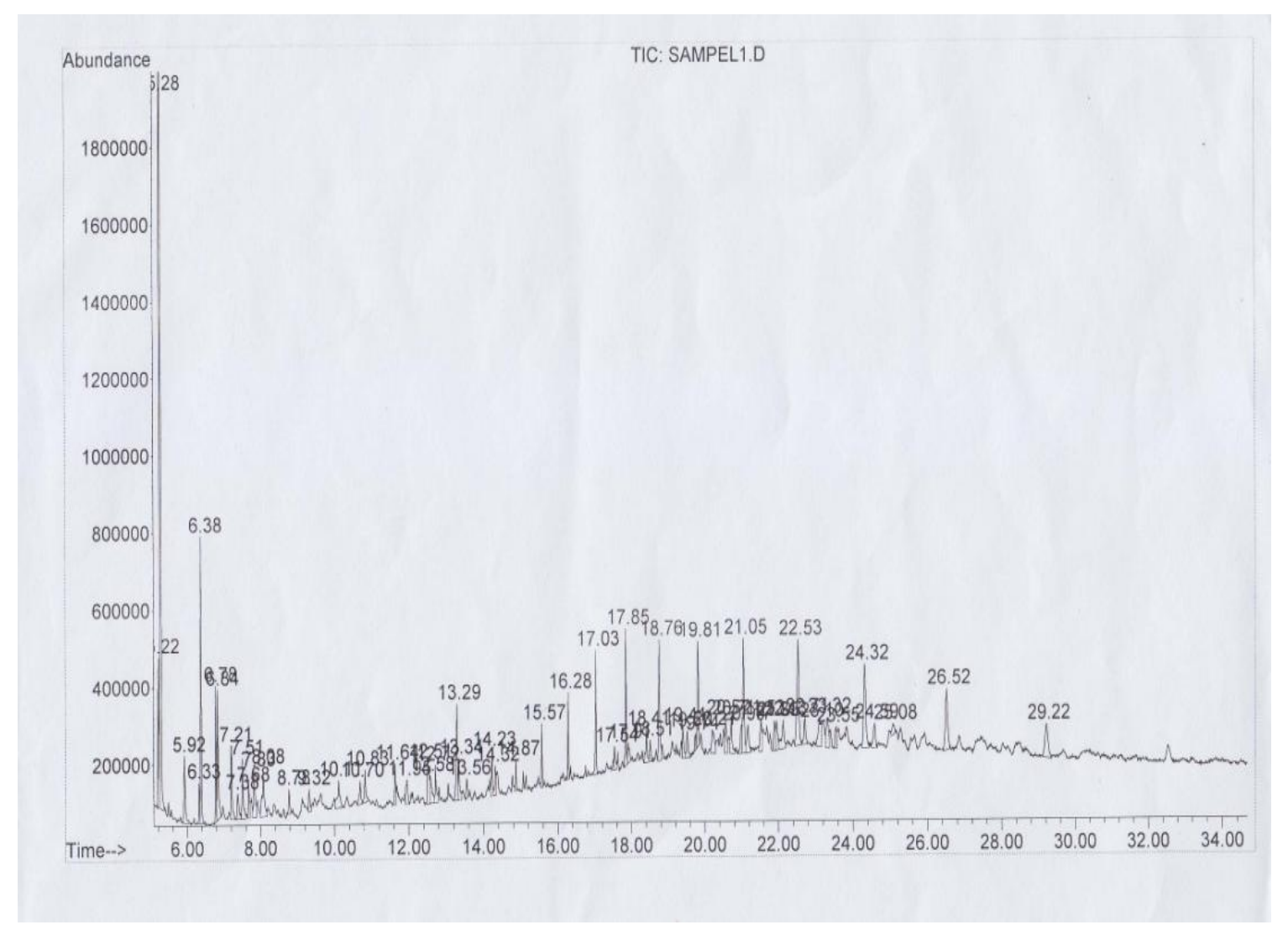

Gambar 4. Hasil ana lisa GCMS ekstrak air daun keco mbrang

Berdasarkan hasil analisa GCMS, sedikitnya 5 golongan senyawa utama yang terkandung dalam ekstrak ait daun kecombrang, yaitu alkana, alkohol, keton, amida dan fenol. Empat diantaranya memiliki luas puncak dan kemiripan yang relative besa yaitu 2,3-butanadiol (1) pada waktu retensi 5,28, luas puncak 29,38 dan kemiripan $90 \%$ dan fenol (2) pada waktu retensi 6,83, luas puncak 2,26 dan kemiripan $90 \%$.<smiles>CC(O)C(C)O</smiles>

\section{2,3-butanadiol}

(1)<smiles>Oc1ccccc1</smiles>

Fenol

(2)

Gambar 5. Senyawa utama dalam ekstrak air daun keco mbrang 


\section{KESIMPULAN DAN SARAN}

\section{Kesimpulan}

Kesimpulam dari pene litian ini adalah:

1. Ekstrak air daun kecombrang bersifat antibakteri E. Coli (zona hambat 10 $\mathrm{mm} / 100 \%$ ), S. Aureus (zona hambat 8,663 $\mathrm{mm} / 20 \%$.

2. Ekstrak air daun kecombrang memiliki komponen utama 2,3-butanadiol $(\mathrm{tR}=5,28$, area $=29,38$, kemiripan $90 \%)$ dan fenol $(\mathrm{tR}=$ 6,83 ,area $=2,26$, kemiripan $90 \%$ ).

\section{Saran}

Pertama, perlu dilakukan pene litian lebih lanjut mengenai isolasi dan penentuan struktur senyawa aktif abtibakteri menggunakan data spektroskopi UV-Vis, IR, dan NMR. Kedua, perlu dilakukan penelitian lebih lanjut mengenai pengujian antibakteri menggunakan bakteri mulut.

\section{UCAPAN TERIMAKASIH}

Ucapan terimakasih disampaikan kepada Ketua Lembaga Penelitian UIN Syarif Hidayatullah yang telah memberi bantuan dana penelitian BLU UIN Syarif Hidayatullah Jakarta, Ketua Pusat Laboratorium Terpadu (PLT) UIN Syarif Hidayatullah jakarta yang telah memfasilitasi penelitian. Balai Tanaman Obat dan Aromatik- Balai Penelitian Tanaman Rempah dan Obat (BALITRO) Kampus Penelitian Cimanggu, Bogor, Pusat Laboratorium Forensik POLRI Kebayoran Baru Jakarta Selatan, dan Laboratorium Badan Pengkajian dan Penerapan Teknologi (BPPT) Jakarta. .

\section{DAFTAR PUSTAKA}

1. Andrew. 2006. Pengawet Alami Pengganti Formalin Sudah ada Sejak Dulu. http: www.andrew57.wordpress.com/2006/03/20/ pengawet-alamipenggantiformalin-sudah-adasejak-dulu. Diakses Rabu, 16 Juli 2008, pk 05:35 WIB.

2. Barus, P. 2009. Pemanfaatan bahan pengawet dan antioksidan alami pada industri bahan makanan. Pidato Pengukuhan Jabatan Guru Besar Tetap dalam Bidang Ilmu Kimia Analitik pada Fakultas Matematika dan Ilmu Pengetahuan Alam, diucapkan di hadapan Rapat
Terbuka Universitas Sumatera Utara. Universitas Sumatra Utara Medan.

3. Best, GK, 1999, Antibacterial Chemotherapy. yang diakses dari sumber http://pharminto.com/publ/msb/newsdrgs.html.

4. Branen A.L dan Davidson PM. 1993. Antimicrobial in Food. Marcel Dekker. New York.

5. Fardiaz, D. 2002. Panduan Pengolahan Pangan yang Baik bagi Industri Rumah Tangga. Jakar: Badan Pengawas Obat dan Makanan.

6. Hidayat dan Hutapea. 1991. Inventaris Tanaman Obat Indonesia. Balai Penelitian dan Pengembangan Departemen Kesehatan RI.

7. Jenie, B.S.L. dan Kuswanto. 1994. Aktivitas antimilcroba dari pigmen angkak yang diproduksi oleh Monasnrs purpuracs terhadap beberapa milcroba patogen dan perusak makanan. Prosiding Pertemuan Ilmiah Tahunan Permi, hal. 53-62.

8. Kanazama, AT. Ikeda T, Endo. 1995. A Novel approach to made of action on cationic biocides: morfological effect on antibacterial activity. $J$ Appl. Bacteriol 78:55-60

9. Prescott, Harley dan Klein. 2005. Microbiology Sixth Edition. Mc Graw Hill Higher Education.

10. Supardi dan Sukamto. 1999. Mikrobiologi dalam Pengelolaan dan Keamanan Pangan. Bandung: ALUMNI.

11.Tranggono, 1990. Bahan Tambahan Pangan (Food Additive). Pusat Antar Universitas. Pangan dan Gizi. UGM. Yogyakarta. 